\title{
Qualidade e valor nutritivo de silagens de capim-marandu (B. brizantha cv. Marandu) produzidas com aditivos ou forragem emurchecida
}

\section{Antonio Fernando Bergamaschine ${ }^{1}$, Milton Passipiéri ${ }^{1}$, Walter Valério Veriano Filho², Olair José Isepon ${ }^{1}$, Luciano de Almeida Correa ${ }^{3}$}

\author{
${ }^{1}$ Departamento de Biologia e Zootecnia da Faculdade de Engenharia - UNESP/Campus de Ilha Solteira, Avenida Brasil, 56 - Centro, Caixa \\ Postal 51, CEP: 15385-000. \\ 2 Departamento de Matemática - UNESP/Campus de Ilha Solteira. \\ ${ }^{3}$ Embrapa Pecuária Sudeste, São Carlos, SP
}

RESUMO - Avaliaram-se a qualidade e o valor nutritivo de silagens de capim-marandu produzidas com polpa cítrica (PC) peletizada, com aditivo enzimático-bacteriano (ABE) ou com forragem emuchercida (E): $\mathrm{T}_{1}$ - forragem sem tratamento (controle); $\mathrm{T}_{2}-10 \%$ de polpa cítrica peletizada (PC); $\mathrm{T}_{3}$ - aditivo enzimático bacteriano (AEB - SIL-ALL-C 4 da Alltech), à base de $5 \mathrm{~g} / \mathrm{L}$ de água/t de forragem; $\mathrm{T}_{4}$ - forragem picada grosseiramente emurchecida por 4 horas ao sol. $\mathrm{O}$ capim foi colhido aos 60 dias de rebrota (24\% MS). Para avaliar o consumo e a digestibilidade das silagens, foram utilizados 16 novilhos mestiços com $200 \mathrm{~kg}$ de PV, que receberam, além das silagens, 1,0 kg de concentrado/animal/dia. O AEB não afetou a composição da silagem, mas a PC e o E aumentaram o teor de MS de $24 \%$ para 31 e $48 \%$, respectivamente, e reduziram o pH e os teores de $\mathrm{N}-\mathrm{NH}_{3}$ das silagens, que foram, respectivamente, de 4,17 e 4,58 e 6,78 e 7,99\% NT. A PC diminuiu os teores de FDN e FDA em 12 e 4 unidades percentuais. O consumo de MS da silagem produzida com capim emurchecido foi superior (111,8 g MS/PV 0 ,75) ao das silagens controle ou com AEB, mas não diferiu do obtido para a silagem com PC, que também não diferiu das demais Os tratamentos não afetaram a digestibilidade, cujas médias para MS, PB, CT, FDN, FDA e NDT foram 67,0; 65,4; 68,8; 63,0; 62,5 ; e $65,6 \%$, respectivamente. A PC e o E reduziram a proteólise e estimularam o consumo. A PC, o E e o AEB não melhoraram o valor nutritivo da silagem de capim-marandu colhido com $24 \% \mathrm{MS}$

Palavras-chave: consumo, digestibilidade, inoculante enzimático-bacteriano, polpa cítrica

\section{Quality and nutritive value of marandugrass (Brachiaria brizanthia, cv. Marandu) silage prepared with additive or wilting}

\begin{abstract}
The objective of this experiment was to evaluate the quality and nutritive value of marandugrass silages. It was evaluated the followings treatments: $\mathrm{T}_{1}$ - forage without treatment (control); $\mathrm{T}_{2}-10 \%$ of pelleted citric pulp (CiP); $\mathrm{T}_{3}$ - enzymatic bacterial additive (EBA) (SIL-ALL-C ${ }_{4}$ of Alltech) applied at $5 \mathrm{~g} / \mathrm{L}$ of water/t of forage; $\mathrm{T}_{4}$ - Coarse chopped forage wilted for 4 hours under the sun. The grass was harvested with 60 days of regrowth $(24 \% \mathrm{DM})$. The intake and digestibility evaluations were realized in 16 crossbred steers with $200 \mathrm{~kg}$ of BW, which received silage plus $1.0 \mathrm{~kg}$ of concentrate/animal/ day. The EBA did not affect silage composition, but CiP addition and wilting increased the DM silage concentration from $24 \%$ (control) to 31 and $48 \%$, respectively. The CiP decreased the NDF and ADF concentration in 12.0 and 4.0 percentage units, respectively. The $\mathrm{CiP}$ and wilting decreased the $\mathrm{pH}$ values $(4.17$ and 4.58$)$ and $\mathrm{N}_{-} \mathrm{NH}_{3}$ concentration $(6.78$ and $7.99 \% \mathrm{TN})$ of the silages, respectively. Wilting resulted in higher animal intake $\left(111.8 \mathrm{~g} / \mathrm{DM} / \mathrm{LW}^{0,75}\right)$ compared to control or EBA treatments. Addition of CiP resulted in similar DM intake compared to other silages. The treatments did not affect nutrient digestibility, and the mean digestibility values for DM, CP, TCHO, NDF, ADF and TDN were 67.0, 65.4, 68.8, 63.0, 62.5, and $65.6 \%$, respectively. Proteolysis was not reduced by EBA while CiP or wilting decreased this process, stimulating intake Addition of CiP, wilting and EBA did not improve the nutritive value of marandugrass silage harvested with $24 \%$ DM.
\end{abstract}

Key Words: citric pulp, digestibility, enzyme bacterial inoculant, intake

\section{Introdução}

O capim-elefante é a gramínea forrageira tropical mais estudada para fins de ensilagem. Entretanto, as gramíneas dos gêneros Panicum (Tanzânia e Mombaça), Brachiaria (brizantha) e Cynodon (Tiftons) também têm sido utiliza- das para ensilagem nos últimos anos. A prática da adubação e do pastejo rotacionado permite elevadas produtividades dessas espécies no verão e possibilita que parte dessa produção seja conservada para suplementação do rebanho em outras épocas do ano. Nussio et al. (2000) afirmaram que a ensilagem de capins tropicais é uma alternativa à ensilagem 
de culturas tradicionais e tem como vantagens o uso de culturas perenes e o aproveitamento do excedente produzido na época das águas.

As gramíneas forrageiras tropicais não apresentam teores adequados de MS e carboidratos solúveis e valores de poder tampão que proporcionem eficiente processo fermentativo. De acordo com Wilkinson et al. (1982), citados por Vilela (1998), a ensilagem de forragens com menos de $21 \%$ de MS, teores de carboidratos solúveis inferiores a 2,2\% na matéria verde e baixa relação carboidratos solúveis x poder tampão apresenta maior possibilidade de fermentações secundárias (indesejáveis). Neste sentido, Reis \& Rosa (2001), analisando diversos trabalhos sobre ensilagem de gramíneas forrageiras tropicais, citaram dados que evidenciam os baixos teores de MS e carboidratos solúveis no momento ideal de colheita. Estas situações podem ser modificadas pelo uso de técnicas como a mistura de produtos à massa ensilada (aditivos) ou pela retirada parcial da água da planta mediante emurchecimento.

Os aditivos reduzem os riscos do processo de ensilagem e melhoram o valor nutritivo da silagem (Vilela, 1998). De acordo com Morais (1999), um bom aditivo para ensilagem de gramíneas tropicais deve apresentar alto teor de matéria seca, ótima capacidade de absorção de água, elevado valor nutritivo, boa palatabilidade e alto teor de carboidratos solúveis, além de fácil manipulação, boa disponibilidade no mercado e baixo custo. Carvalho (1994) verificou estas características na polpa cítrica e enfatizou sua capacidade de absorção de água ( $145 \%$ do seu peso) e seu teor de carboidratos solúveis (aproximadamente 25\% da MS).

Amaral et al. (2004) e Ribeiro et al. (2004) observaram que a adição de 5 ou $10 \%$ de polpa cítrica peletizada na ensilagem do capim-marandu diminuiu os teores dos componentes da parede celular e o $\mathrm{pH}$ e aumentou os teores de $\mathrm{PB}$ e a digestibilidade in vitro da MS da silagem. Coan et al. (2004) não detectaram alteração no pH, mas observaram diminuição nos teores de nitrogênio amoniacal $\left(\mathrm{N}-\mathrm{NH}_{3}\right)$ da silagem de capim-marandu quando usaram 5 ou $10 \%$ de polpa cítrica como aditivo.

Conforme a classificação de McDonald et al. (1991), os inoculantes ou culturas bacterianas e as enzimas que degradam a parede celular pertencem a duas diferentes classes de aditivos. Entretanto, a maioria dos produtos comerciais é uma combinação de bactérias láticas e de várias enzimas (Corrêa \& Pott, 2001). De acordo com Rotz \& Muck (1994) e Wilkinson (1998), os aditivos bacterianos têm como função aumentar a população de bactérias láticas e incrementar a taxa de fermentação pelo uso mais eficiente dos carboidratos solúveis, elevando a produção de ácido lático e reduzindo o $\mathrm{pH}$ e o teor de $\mathrm{N}-\mathrm{NH}_{3}$. Wilkinson (1998) afirma ainda que os aditivos bacterianos podem aumentar o teor de EM da silagem, como resultado da degradação de fibra indigestível no rúmen.

Ribeiro et al. (2004) concluíram que o uso de inoculantes (Lactobacillus plantarum ou Buchneri) na ensilagem do capim-marandu não foi efetivo em preservar a proteína e não teve efeito sobre a fração fibra ou sobre a digestibilidade in vitro da MS da silagem. Ao avaliarem a adição de um produto comercial à base de enzimas e bactérias na ensilagem do capim-elefante, Henrique \& Bose (1992) não detectaram mudanças nas composições protéica e fibrosa, nos teores de $\mathrm{N}_{-} \mathrm{NH}_{3}$ e no $\mathrm{pH}$ da silagem.

Lavezzo (1993) destacou que a excessiva umidade da forragem, caracterizada por teor de MS inferior a 20\%, no momento da ensilagem reduz os efeitos preservativos das fermentações ácidas primárias e não restringe o crescimento de bactérias do gênero Clostridium em pH de 3,8 a 4,0. Esse autor afirma que a remoção parcial de água da planta via emurchecimento visa limitar a fermentação na ensilagem, reduzir a incidência de fermentações secundárias e diminuir ou eliminar a formação de efluente.

Pereira \& Reis (2001) relataram que as plantas forrageiras, quando cortadas para conservação, apresentam teor de umidade de 80 a $85 \%$, que reduz rapidamente para $65,8 \%$. Com esta umidade, é improvável a formação de efluente ou a ocorrência de fermentações indesejáveis no silo. Assim, pode-se afirmar que a ensilagem de forragem emurchecida oferece menor risco de perdas com chuvas, pois a forragem fica menos tempo no campo, sendo uma alternativa à fenação. Segundo Ribeiro et al. (2004), o emurchecimento do capim-marundu antes da ensilagem proporciona maiores teores de $\mathrm{PB}$ e FDN, mas não afeta o teor de FDA e a DVIV da MS.

Considerando as poucas informações sobre técnicas de ensilagem de gramíneas forrageiras tropicais, realizou-se esta pesquisa com o objetivo de avaliar a qualidade fermentativa, a composição química, o consumo e a digestibilidade in vivo de silagens de Brachiaria brizantha cv. Marandu produzidas com polpa cítrica peletizada, aditivo enzimático bacteriano ou forragem emurchecida.

\section{Material e Métodos}

O experimento foi conduzido na Fazenda de Ensino, Pesquisa e Extensão da Faculdade de Engenharia, UNESP, Campus de Ilha Solteira, no município de Selvíria, Mato Grosso do Sul.

O capim-marandu foi semeado em área de pastagem degradada, após recuperação (por dois anos consecutivos) do cultivo de milho. Após um ano de utilização em pastejo, 
uma área de aproximadamente 1 ha foi vedada em meados de outubro de 2002; no final de novembro, a forragem foi rebaixada com roçadeira mecanizada a $20 \mathrm{~cm}$ de altura do solo e, em seguida, a área foi adubada com $50 \mathrm{~kg} \mathrm{~N} / \mathrm{ha} \mathrm{na}$ forma de sulfato de amônio. Após 60 dias de crescimento (dezembro e janeiro de 2003), quando a gramínea encontravase no estádio de emborrachamento, realizou-se a colheita para ensilagem, utilizando-se colhedeira de forragem modelo CF-760 da Siltomac. O corte foi realizado a $20 \mathrm{~cm}$ do solo e a forragem, cortada em partículas (segundo o fabricante) de aproximadamente $4 \mathrm{~cm}$. Os silos eram de alvenaria, tipo poço, com capacidade para 2,4 toneladas.

Os tratamentos corresponderam a quatro diferentes formas de otimização da fermentação da forragem: $\mathrm{T}_{1}$ - controle (apenas forragem); $\mathrm{T}_{2}-$ forragem $+10 \%$ de polpa cítrica peletizada (PC); $\mathrm{T}_{3}-$ forragem + aditivo enzimático bacteriano (AEB); $\mathrm{T}_{4}$ - forragem previamente emurchecida (E). A quantidade de PC utilizada foi $10 \%$ da matéria natural. O AEB utilizado foi o SIL-ALL $\mathrm{C}_{4}$ da Alltech, que apresentava como garantia Streptococcus faecium, Lactobacillus plantaram e Lactobacillus salivarius (na proporção de 10 bilhões de UFC/g de cada espécie) e enzimas hemicelulase e celulase (5\%). O aditivo foi aplicado com pulverizador costal novo, na dosagem de $5 \mathrm{~g} / \mathrm{t}$ de forragem (dissolvido em $1 \mathrm{~L}$ de água mineral), calibrando-se o tempo de aplicação para determinado volume e quantidade de forragem colocada no silo. O murchecimento foi realizado na forragem grosseiramente picada e exposta ao sol por 4 horas (10 a 14h). Em seguida, a forragem foi recolhida e novamente picada com a mesma máquina utilizada para o corte.

O enchimento dos silos foi realizado em camadas de aproximadamente $5 \mathrm{~cm}$, que correspondiam a $23 \mathrm{~kg}$ de forragem. Este procedimento permitiu a mistura da forragem com os aditivos nas proporções estipuladas, de forma mais uniforme e com mais eficiente compactação (pisoteio de duas pessoas). Após mistura da forragem com os aditivos dentro do silo, coletaram-se seis amostras de aproximadamente $1 \mathrm{~kg}$ de forragem por tratamento, as quais foram acondicionadas em sacos plásticos e imediatamente armazenadas em congelador a $-10^{\circ} \mathrm{C}$. Após o enchimento, os silos foram vedados com lona plástica e uma camada de $10 \mathrm{~cm}$ de terra sobreposta. Todos os silos foram mantidos sob telhado de zinco, a $60 \mathrm{~cm}$ do topo.

Após 40 dias de fermentação, os silos foram abertos para determinação da composição química das silagens e estudo do consumo e da digestibilidade. Durante o uso das silagens, a cada três dias, foram coletadas amostras (seis por tratamento), que foram identificadas e congeladas a $-10^{\circ} \mathrm{C}$ para análises posteriores. Nos estudos do consumo de MS e da digestibilidade dos nutrientes, foram utilizados 16 bovinos mestiços de origem leiteira, com 12 a 13 meses de idade e 185 a $215 \mathrm{~kg}$ de PV. Os animais foram desverminados e vacinados contra carbúnculo sintomático e febre aftosa. Inicialmente, foram adaptados ao confinamento por 15 dias, quando receberam silagem de capim-colonião e $1 \mathrm{~kg}$ de concentrado, além de sal mineral e água à vontade. Após este período, foram pesados e distribuídos em um delineamento de blocos casualizados, com quatro tratamentos e quatro repetições, adotando-se o peso vivo para formação dos blocos.

Os animais foram mantidos no experimento por 29 dias, sendo 20 em baias individuais, para adaptação às silagens e avaliação do consumo de MS, realizado nos últimos cinco dias, e nove dias em gaiolas de estudos metabólicos (dois de adaptação e sete de coleta total de fezes). No período de adaptação, as silagens foram oferecidas duas vezes ao dia (7h30 e 15h30) em quantidade suficiente para ocorrer sobras de aproximadamente $10 \%$ do oferecido. No período de coleta, a quantidade de forragem foi restringida conforme o consumo, de modo que as sobras fossem mínimas. Além das silagens, foi fornecido $1,0 \mathrm{~kg}$ de concentrado/animal/dia $(64,5 \% /$ milho $+33 \%$ farelo de soja $+2,5$ sal mineral $)$.

Diariamente, duas vezes ao dia $(16$ e $8 \mathrm{~h})$, foram coletadas amostras de fezes, retirando-se, após pesagem e homogeneização, alíquotas de $5 \%$, que foram acondicionadas em saco plástico devidamente identificado e armazenadas em congelador $\left(-10^{\circ} \mathrm{C}\right)$. Eventuais sobras de alimentos foram pesadas, amostradas por animal e congeladas. No final do período de coleta, formaram-se amostras compostas das fezes e das sobras, obtendo-se uma amostra média por animal.

$\mathrm{Na}$ forragem fresca, foi determinado o teor de carboidratos solúveis (CHOS) pelo método colorimétrico (Johnson et al., 1966). No suco da silagem, obtido por prensagem, foi medido o $\mathrm{pH}$ com potenciômetro digital e, na forragem seca e moída, foi determinado o poder tampão, conforme descrito por Playne \& McDonald (1966). Nas amostras de forragem e de silagens secas e moídas, foram determinados os teores de MS, PB, EE, CIN, FDN, FDA e LIG, segundo metodologia descrita por Silva (1990). Nas silagens também foram determinados os teores de nitrogênio insolúvel em detergente neutro (NIDN), nitrogênio insolúvel em detergente ácido (NIDA), nitrogênio não-protéico (NNP) e nitrogênio solúvel, conforme descrito por Malafaia \& Vieira(1997).

$\mathrm{Na}$ interpretação estatística dos dados obtidos nas forragens ensiladas, adotou-se o delineamento inteiramente 
casualizado e, para os dados obtidos nas silagens e aqueles referentes ao consumo e à digestibilidade, utilizou-se o delineamento em blocos ao acaso. As análises foram realizadas pelo procedimento GLM (SAS, 1990) e as médias foram comparadas pelo teste Tukey a $5 \%$ de probabilidade.

\section{Resultados e Discussão}

Os dados referentes à composição bromatológica da forragem ensilada, de acordo com os tratamentos, são apresentados na Tabela 1. O emurchecimento durante 4 horas sob sol intenso aumentou $(\mathrm{P}<0,01)$ o teor de MS da forragem. A adição de $10 \%$ de PC não afetou significativamente o teor de MS, mas promoveu aumento de 4,42 unidades percentuais em relação à forragem controle, proporcionando teor de MS de 29,13\%. Esse valor é superior ao de $25 \%$ sugerido por Haigh (1999) para a mínima formação de efluente e próximo ao de $30 \%$ preconizado por Rotz \& Muck (1994) para limitar o crescimento de bactérias do gênero Clostridium. Assim, as silagens sem tratamento ( $\mathrm{T}$ ) e com aditivo enzimático-bacteriano estiveram sujeitas a fermentações indesejáveis. O emurchecimento, quando comparado aos demais tratamentos, diminuiu $(\mathrm{P}<0,01)$ o teor de $\mathrm{PB}$ da forragem, o que pode estar relacionado à perda de proteína solúvel pelo extravasamento do conteúdo celular durante o emurchecimento ou à perda de fragmentos de folhas durante o recolhimento da forragem emurchecida. Contrariamente, Narciso Sobrinho et al. (1998a) observaram que o emurchecimento aumentou o teor de PB da forragem e atribuíram o fato ao efeito de concentração decorrente da perda de umidade da forragem.

Tabela 1 - Teores (\%) de MS, PB, CHOS, FDN e FDA e poder tampão das silagens avaliadas

Table 1 - Concentrations of DM, CP, buffering capacity (BC), SC, NDF, and $A D F$ in the evaluated silages

\begin{tabular}{|c|c|c|c|c|c|}
\hline \multicolumn{2}{|c|}{$\begin{array}{l}\text { Parâmetro }(\% \mathrm{MS}) \\
\text { Parameter }(\% \quad D M)\end{array}$} & \multicolumn{2}{|c|}{$\begin{array}{c}\text { Tratamento } \\
\text { Treatment }\end{array}$} & \multirow{2}{*}{ E } & \multirow[t]{3}{*}{ CV $(\%)$} \\
\hline & $\mathrm{T}$ & $\mathrm{PC}$ & AEB & & \\
\hline & C & $\mathrm{CiP}$ & $E B A$ & $W$ & \\
\hline $\mathrm{MS}(D M)$ & $24,71 b$ & $29,13 b$ & $24,03 b$ & $43,78 a$ & 10,64 \\
\hline $\mathrm{PB}(C P)$ & $8,99 \mathrm{a}$ & $8,49 \mathrm{a}$ & $8,46 a$ & $7,18 \mathrm{~b}$ & 6,75 \\
\hline $\mathrm{PT}^{1}(B C)$ & $28,05 \mathrm{~b}$ & $30,95 \mathrm{a}$ & $26,88 b$ & $24,40 \mathrm{c}$ & 3,17 \\
\hline $\mathrm{CHO}$ (SSC) & $2,67 \mathrm{a}$ & $3,16 \mathrm{a}$ & $2,23 \mathrm{a}$ & $2,50 \mathrm{a}$ & 31,20 \\
\hline FDN (NDF) & $72,98 \mathrm{a}$ & $60,68 \mathrm{~b}$ & $74,40 \mathrm{a}$ & $73,95 \mathrm{a}$ & 2,63 \\
\hline FDA $(A D F)$ & $42,72 \mathrm{a}$ & $39,45 b$ & $42,58 \mathrm{a}$ & $42,33 \mathrm{a}$ & 3,21 \\
\hline
\end{tabular}

T. Forragem sem tratamento; PC - forragem com polpa cítrica; AEA forragem com aditivo enzimático-bacteriano; $\mathrm{E}$ - forragem emurchecida. 1 e.mq HCl/100g MS.

Médias seguidas por letras distintas, na linha, são diferentes $(P<0,05)$. C. Forage without treatment; CiP - forage with citric pulp; EBA - forrage with enzimaticbacterial additive; $W$ - wilted forage; eq. $m g \mathrm{Cl} / \mathrm{H} / 100 \mathrm{~g} D \mathrm{DM}$.

Means follwed by distinct letters in the same row differ $(P<0.05)$.
A adição de $\mathrm{PC}$ aumentou $(\mathrm{P}<0,01)$ e o emurchecimento diminuiu $(\mathrm{P}<0,01)$ o poder tampão das silagens quando comparados ao uso de aditivo enzimático-bacteriano (AEB). Peres (1997), ao adicionar polpa cítrica na ensilagem de capim-elefante, também constatou aumento do PT. De acordo com Igarasi (2000), este resultado está relacionado ao alto teor de cálcio da polpa cítrica. Quanto ao emurchecimento, a literatura revisada por Lavezzo (1993) indica que o PT não tem comportamento definido face à alteração do teor de MS. Os valores observados foram próximos do valor mínimo de 25 e.mg HCl/100 g MS sugerido por McDonald (1991) para capins.

Os teores de CHOS não foram afetados pelos tratamentos. Contrariando este resultado, Peres (1997) obteve aumento de $52 \%$ (7,6 para $11,6 \%$ ) no teor de CHOS com adição $10 \%$ de polpa cítrica peletizada na ensilagem do capim-elefante. Considerando-se a proporção de forragem e PC (90:10) utilizada neste trabalho, os teores de MS e CHOS da forragem (24,7 e 2,67\% MS - Tabela 1) e da polpa cítrica ( 82 e $28 \%$ MS) (Carvalho, 1994), pode-se estimar o teor de CHOS da mistura como 10\% MS. Como pode ser observado na Tabela 1, esse valor não foi alcançado, provavelmente porque a trituração das amostras em liquidificador, em vez da moagem para passagem em peneira de $2 \mathrm{~mm}$, pode não ter permitido eficiente extração dos CHOS em água, o que resultou em valores subestimados.

$\mathrm{O}$ emurchecimento não afetou $(\mathrm{P}<0,05)$ os teores de CHOS, entretanto, Narciso Sobrinho et al. (1998) e Berto \& Mühlback (1997) verificaram diminuição nos teores de CHOS com o emurchecimento da forragem, fato atribuído à respiração celular. A média (2,64\% MS) dos valores observados foi menor que o mínimo de 8 a 10\% MS preconizado por McDonald (1991) para adequada fermentação.

Como relatado por Peres (1997) e Igarasi (2002), também neste trabalho os teores de FDN e FDA diminuíram $(\mathrm{P}<0,05)$ com a adição de polpa cítrica. Esses autores atribuíram este resultado ao menor teor de fibra da PC em relação ao capim, ocorrendo, portanto, diluição da fibra da silagem resultante.

Os parâmetros da composição química das silagens são descritos na Tabela 2. O emurchecimento proporcionou silagem com o maior $(\mathrm{P}<0,01)$ teor de MS. O alto teor de MS $(47,97 \%)$ causou intenso desenvolvimento de mofo nas laterais do silo. Vilela (1998) recomendou teor de MS de 40 a $45 \%$ como mais apropriado à ensilagem e ressaltou que valor acima de $50 \%$ dificulta a compactação no silo, criando condições favoráveis ao desenvolvimento de mofo. A adição de $10 \%$ de $\mathrm{PC}$ proporcionou silagem com maior $(\mathrm{P}<0,01)$ teor de MS $(31,17 \% \mathrm{MS})$ em relação à silagem controle $(24,10 \%$ MS). O teor de $31,17 \%$ MS é ideal para o bom 
processo fermentativo. Igarasi (2000), trabalhando com capim-tanzânia colhido aos 45 dias de rebrota, obtiveram silagens com 16,5 e 26,5\% MS ao adicionarem, respectivamente, zero ou 15\% de polpa cítrica. Corrêa \& Pott (2001), ensilando a mesma espécie colhida com 55 dias de crescimento, observaram 21 e $24 \%$ de MS na silagem produzida sem aditivo ou com $7 \%$ de PC, respectivamente.

Os teores de $\mathrm{PB}$ das silagens não foram afetados $(\mathrm{P}<0,05)$ pelos tratamentos. Entretanto, Reis et al. (2004) e Ribeiro et al. (2004), trabalhando com capim-marandu, observaram aumento de até $12 \%$ nos teores de PB na silagem com $10 \%$ de PC ou com forragem emurchecida. Esses tratamentos, de acordo com os autores, reduziram a atividade proteolítica, preservando a fração protéica. Neste trabalho, a adição de PC e o emurchecimento também reduziram a proteólise, pois proporcionaram os menores $(\mathrm{P}<0,01)$ teores de $\mathrm{N}-\mathrm{NH}_{3}$. É possível, no entanto, que tenha ocorrido uma diminuição concomitante no teor de PB com a adição de polpa cítrica, como resultado do efeito de diluição e do emurchecimento decorrente da perda de conteúdo celular, de modo a manter os teores de PB similares entre os tratamentos. A concentração de $\mathrm{N}-\mathrm{NH}_{3}$ diminuiu $(\mathrm{P}<0,01)$ em resposta à adição de PC e está de acordo com as observações de Coan et al. (2004) e Reis et al. (2004). A polpa cítrica, além de reduzir a umidade, contém CHOS, que possibilitam a formação de ácido lático

Tabela 2 - Teores de MS, PB, N-NH 3 , NIDN, NIDA, NS, NNP, EE, CIN, CT, FDN, FDA e LIG das silagens

Table 2 - Concentrations of DM, CP, $p H$ value, $N_{3}-N, N D I N, A D I N, S N$, $N P N, E E$, ash, TC, NDF, ADF, and lignin of the silages

\begin{tabular}{|c|c|c|c|c|c|}
\hline \multirow{3}{*}{$\begin{array}{l}\text { Parâmetro }(\% \mathrm{M} \\
\text { Parameter }(\% \quad D M)\end{array}$} & \multicolumn{4}{|c|}{$\begin{array}{c}\text { Tratamento } \\
\text { Treatment }\end{array}$} & \multirow[t]{3}{*}{ CV $(\%)$} \\
\hline & \multirow{2}{*}{$\begin{array}{l}\mathrm{T} \\
\mathrm{C}\end{array}$} & \multirow{2}{*}{$\begin{array}{l}\mathrm{PC} \\
\text { CiP }\end{array}$} & \multirow{2}{*}{$\begin{array}{c}\mathrm{AEB} \\
E B A\end{array}$} & \multirow{2}{*}{$\begin{array}{l}\mathrm{E} \\
W\end{array}$} & \\
\hline & & & & & \\
\hline $\operatorname{MS}(D M)$ & $24,10 \mathrm{c}$ & $31,07 b$ & $25,18 \mathrm{c}$ & $47,97 \mathrm{a}$ & 3,88 \\
\hline $\mathrm{PB}^{1}(C P)$ & $7,32 \mathrm{a}$ & $7,65 \mathrm{a}$ & $7,58 \mathrm{a}$ & $6,67 \mathrm{a}$ & 9,46 \\
\hline $\mathrm{pH}$ & $4,94 \mathrm{a}$ & $4,17 \mathrm{c}$ & $4,71 \mathrm{ab}$ & $4,58 \mathrm{~b}$ & 3,85 \\
\hline $\mathrm{N}-\mathrm{NH}_{3}^{2}$ & $34,78 \mathrm{a}$ & $6,78 b$ & $27,78 \mathrm{a}$ & $7,99 b$ & 32,41 \\
\hline $\mathrm{NIDN}^{2}(N D I N)$ & $18,50 \mathrm{a}$ & $19,28 \mathrm{a}$ & $16,01 \mathrm{a}$ & $18,87 \mathrm{a}$ & 13,57 \\
\hline $\mathrm{NIDA}^{2}(A D I N)$ & $12,85 \mathrm{~b}$ & $15,63 \mathrm{a}$ & $13,14 \mathrm{ab}$ & $12,70 \mathrm{~b}$ & 10,77 \\
\hline $\mathrm{NS}^{2}(S N)$ & $62,18 \mathrm{ab}$ & $57,04 \mathrm{~b}$ & $64,31 \mathrm{a}$ & $59,81 \mathrm{a}$ & 6,07 \\
\hline $\mathrm{NNP}^{2}(N P N)$ & $57,10 \mathrm{a}$ & $53,90 \mathrm{a}$ & $57,24 \mathrm{a}$ & $59,18 \mathrm{ab}$ & 7,67 \\
\hline $\mathrm{EE}^{1}$ & $2,39 b$ & $2,45 b$ & $2,79 a$ & $1,67 \mathrm{c}$ & 6,62 \\
\hline $\mathrm{CIN}^{1}(A s h)$ & $7,56 \mathrm{ab}$ & $7,00 \mathrm{bc}$ & $8,16 \mathrm{a}$ & $6,69 \mathrm{c}$ & 5,29 \\
\hline $\mathrm{CT}^{1}(T C)$ & $82,72 b$ & $82,89 \mathrm{~b}$ & $81,43 b$ & $84,96 \mathrm{a}$ & 1,01 \\
\hline $\mathrm{FDN}^{1}(N D F)$ & $73,93 \mathrm{ab}$ & $62,11 \mathrm{c}$ & $71,88 \mathrm{~b}$ & $75,16 \mathrm{a}$ & 1,68 \\
\hline $\mathrm{FDA}^{1}(A D F)$ & $47,23 a$ & $43,64 b$ & $46,14 \mathrm{a}$ & $44,32 b$ & 1,57 \\
\hline LIG $^{1}$ (Lignin) & $4,42 \mathrm{a}$ & $4,51 \mathrm{a}$ & $4,51 \mathrm{a}$ & $4,52 \mathrm{a}$ & 8,13 \\
\hline
\end{tabular}

T - controle; PC - polpa cítrica. AEB - aditivo enzimático-bacteriano; E - emurchecimento.

1 Porcentagem da MS; 2 Porcentagem do nitrogênio total.

Médias seguidas de letras distintas, na linha, são diferentes $(P<0,05)$.

${ }^{1}$ Dry matterpercentage; ${ }^{2}$ Total nitrogen percentage

C. control; CiP - citric pulp; EBA - enzimatic-bacerial additive; $W$ - Wilting.

Means followed by distinct letters in the same row differ $(P<.05)$. e a concomitante queda no $\mathrm{pH}$, que limitam o desenvolvimento de bactérias do gênero Clostridium.

Embora o uso de polpa cítrica não tenha, aparentemente, alterado o teor de CHOS na forragem, a silagem resultante apresentou o menor $(\mathrm{P}<0,01)$ valor de $\mathrm{pH}$, próximo de 4,2 , acima do qual a qualidade da silagem é comprometida. O emurchecimento aumenta a pressão osmótica limitando a fermentação, por isso, ocorreu menor redução do pH e baixa produção de amônia. De acordo com Igarasi (2002), o emurchecimento do capim-tanzânia não alterou o $\mathrm{pH}$, mas diminuiu a formação de $\mathrm{N}-\mathrm{NH}_{3}$ na silagem.

$\mathrm{O}$ aditivo enzimático-bacteriano não foi eficiente em alterar o perfil da fermentação no silo, proporcionando silagem com $\mathrm{pH}$ e teores de $\mathrm{N}-\mathrm{NH}_{3}$ e NS estatisticamente iguais aos da silagem de forragem controle. Henrique \& Bose (1992), trabalhando com capim-elefante, e Rodrigues et al. (2002), em estudo com sorgo, não obtiveram resposta ao uso de aditivo enzimático bacteriano sobre o $\mathrm{pH}$ e o teor de $\mathrm{N}^{-\mathrm{NH}_{3}}$, enquanto Berto \& Mühlback (1997), em experimento com aveia, concluíram que o emurchecimento e o uso de aditivos bacterianos e sua associação com enzimas reduziram o $\mathrm{pH}$ e o teor de $\mathrm{N}-\mathrm{NH}_{3}$. Wilkinson (1998) afirmou que os inoculantes bacterianos podem ser ineficientes se a população natural de bactérias for muito alta ou o teor de CHOS na forragem for baixo. De acordo com Nussio et al. (2001), os aditivos bacterianos devem ser adicionados durante o corte e a picagem, e não durante o enchimento do silo, sob pena de não prevalecerem sobre a flora epifítica.

Os teores de NIDN não foram $(\mathrm{P}<0,05)$ influenciados pelos tratamentos, entretanto, Peres (1997), em silagem de capim-elefante, e Reis et al. (2004), em silagem de capimmarandu observaram aumento nos teores de NIDN com a adição de 10\% de polpa cítrica. Peres (1997) relacionou esse resultado ao considerável teor de nitrogênio ligado à fibra da polpa cítrica. Berto \& Mühlback (1997) não detectaram efeito do aditivo enzimático-bacteriano sobre os teores de NIDN da silagem de aveia, mas notaram aumento na fração deste nutriente com o emurchecimento. A adição de polpa cítrica aumentou $(\mathrm{P}<0,05)$ o teor de NIDA da silagem de 12,85 para $15,63 \%$ do NT. Peres (1997) também observou aumento do teor de NIDA (12,9 para $16,7 \%$ NT) na silagem de capim-elefante em resposta à adição de polpa cítrica. Segundo esse autor, o aquecimento da polpa cítrica durante a secagem pode levar à formação de complexos insolúveis entre carboidratos e proteína (Reação de Maillard), o que resulta em maior teor de NIDA. Igarasi (2002) e Reis et al. (2004) não observaram efeito da adição de PC no teor NIDA da silagem.

Os teores de NS diminuíram $(\mathrm{P}<0,05)$ com adição de polpa cítrica. A diminuição da umidade e do $\mathrm{pH}$ da silagem 
com a presença da polpa cítrica pode ter reduzido a proteólise na silagem, diminuindo o teor de NS. Todavia, os teores de NNP das silagens não foram $(\mathrm{P}>0,05)$ afetados pelos tratamentos e, geralmente, todo NS de silagens está na forma de NNP. Perez (1997) enfatizou que as frações de NS e NNP são constituídas basicamente de $\mathrm{N}-\mathrm{NH}_{3}$, que pode volatizar no momento da secagem das amostras em estufa, o que altera o resultado de análises dessas frações. Os teores de NNP das silagens foram elevados, porém, de acordo com Pereira \& Reis (2001), altos teores desta fração do nitrogênio são característicos de silagens. Esses autores afirmaram que o teor de NNP na forragem varia de 10 a $25 \%$ e que, com a ensilagem ocorre intensa proteólise, que eleva estes valores para 40 a $60 \%$ do nitrogênio total.

$\mathrm{O}$ emurchecimento diminuiu $(\mathrm{P}<0,01)$ o teor de EE da silagem, o que pode ser conseqüência da perda de pigmentos como caroteno e clorofila, que são extraídos com éter. Além disso, o alto teor de MS pode ter limitado a fermentação e, portanto, a produção de ácidos orgânicos que também compõem o EE. O menor $(\mathrm{P}<0,05)$ teor de CIN da silagem produzida com forragem emurchecida pode estar relacionado ao extravasamento de conteúdo celular durante a secagem no campo ou à perda de folhas da forragem durante o recolhimento mecânico da forragem emurchecida e parcialmente picada.

Para a silagem produzida com PC, o menor teor de CIN pode ser resultado do efeito de diluição, pois sua fração na polpa cítrica, de acordo com Carvalho (1994), pode variar de 3 a $16 \%$. Os menores teores de PB, EE e CIN, causados pelo emurchecimento da forragem, possibilitaram maior $(\mathrm{P}<0,01)$ valor de CT.

A adição de $\mathrm{PC}$ proporcionou menores $(\mathrm{P}<0,01)$ teores de FDN e FDA na silagem, provavelmente em razão da diluição ocasionada pelo menor teor de fibra da PC, o que está de acordo com os resultados observados por Ribeiro et al. (2004) e Amaral et al. (2004), que utilizaram PC na ensilagem de capim-marandu. $\mathrm{O}$ emurchecimento não afetou o teor de FDN, mas diminuiu $(\mathrm{P}<0,01)$ o de FDA, em comparação à ausência de tratamento (controle). Este resultado não parece consistente, pois possíveis perdas de nutrientes solúveis durante o emurchecimento provocariam aumento no teor de FDA. Ribeiro et al. (2004) observaram aumento no teor de FDN, mas nenhum efeito sobre o teor de FDA da silagem de capim-marandu emuchercido. Igarasi et al. (2002) também não detectaram efeito do emurchecimento sobre a fibra do capim-tanzânia.

$O$ aditivo enzimático-bacteriano não afetou $(\mathrm{P}<0,05)$ os teores de FDN e FDA, como observado por Henrique \& Bose (1992) e Berto \& Mühlback (1997), que trabalharam, respectivamente, com capim-elefante e aveia. De acordo com Wilkinson (1998), o uso de enzimas na ensilagem tem como finalidade aumentar a disponibilidade de carboidratos solúveis para as bactérias láticas, com conseqüente diminuição do $\mathrm{pH}$, e para elevar a digestibilidade da MO.

Na Tabela 3 encontram-se os dados de consumo de MS, em kg/dia, \%PV e g/kgPV ${ }^{0,75}$. Independentemente da unidade de expressão, o emurchecimento proporcionou o maior $(\mathrm{P}<0,01)$ consumo de $\mathrm{MS}$, em relação às silagens controle e com aditivo enzimático bacteriano, e consumo similar ao da silagem com $\mathrm{PC}$, que não diferiu $(\mathrm{P}<0,05)$ das demais. $\mathrm{O}$ alto teor de MS (48\%) proporcionado pelo emurchecimento da forragem restringiu a fermentação no silo e, conseqüentemente, a formação de ácidos orgânicos e a proteólise. Lavezzo (1993) relatou que, de modo geral, a redução no consumo de silagem é causada pelas mudanças químicas durante a fermentação e que muitos estudos mostraram correlação positiva consumo de MS x teor de MS na silagem, de modo que $35 \%$ de MS possibilitaria maior consumo. Silveira et al. (1980) e Narciso Sobrinho et al. (1998) verificaram melhora significativa no consumo de MS da silagem de capim-elefante em resposta ao emurchecimento.

Wright et al. (2000) revisaram 85 trabalhos sobre os fatores que afetam o consumo e o desempenho de animais alimentados com silagem de capim produzida com forragem emurchecida e concluíram que a perda total de água, a velocidade de perda de água da forragem emurchecida, as características da forragem (como teores de $\mathrm{PB}$ e N-NH${ }_{3}$ ) e a digestibilidade da MS da silagem proveniente da forragem não-emurchecida são as variáveis mais exatas e positivamente correlacionadas ao aumento do consumo de MS, como resultado do emurchecimento.

De acordo com McDonald et al. (1991), o consumo de MS da silagem é positivamente correlacionado aos teores de MS, PB e ácido lático e negativamente correlacionado aos de ácido acético, ácidos graxos voláteis totais e $\mathrm{N}^{-\mathrm{NH}_{3}}$. Pode-se inferir, portanto, que a PC estimulou a fermentação e os ácidos orgânicos produzidos afetaram o consumo, pois o teor de $\mathrm{N}-\mathrm{NH}_{3}$ foi tão baixo quanto na silagem de forragem emurchecida. Provavelmente, o fornecimento de concentrado estimulou o consumo de MS das silagens produzidas com forragens sem tratamento ou com aditivo enzimáticobacteriano, de modo a reduzir a diferença entre o consumo destas silagens e o da silagem produzida com PC. Peres (1997) observou aumento significativo no consumo de MS com adição de PC na ensilagem de capim-elefante, entretanto, a silagem sem aditivo apresentava apenas 19\% de MS.

$\mathrm{O}$ uso de aditivo enzimático-bacteriano não afetou o consumo de MS. Esse resultado confirma os relatos de 
Tabela 3 - Consumo de MS (silagem + concentrado) e coeficiente de digestibilidade aparente dos nutrientes das silagens avaliadas

Table 3 - $\quad$ DM intake (silage + concentrate) and apparent digestibility coefficients of the nutrients in the diets

\begin{tabular}{lllll}
\hline Parâmetro $(\% \mathrm{MS})$ & \multicolumn{3}{c}{ Tratamento } & CV $(\%)$ \\
Parameter $(\%$ DM) & \multicolumn{4}{c}{ Treatment } \\
\cline { 2 - 5 } & $\mathrm{T}$ & PC & AEB & E \\
& $C$ & CiP & EBA & $W$ \\
\hline
\end{tabular}

Consumo de MS

DM intake

\begin{tabular}{lrrrrr}
$\mathrm{kg} / \mathrm{dia}$ & $4,71 \mathrm{~b}$ & $5,33 \mathrm{ab}$ & $4,67 \mathrm{~b}$ & $5,83 \mathrm{a}$ & 7,94 \\
$\mathrm{~kg} /$ day & & & & & \\
$\begin{array}{l}\% \mathrm{PV} \\
\% B W\end{array}$ & $2,34 \mathrm{~b}$ & $2,69 \mathrm{ab}$ & $2,37 \mathrm{~b}$ & $2,99 \mathrm{a}$ & 7,03 \\
$\mathrm{~g} / \mathrm{kg} \mathrm{PV} \mathrm{PV}^{0,75}$ & $87,69 \mathrm{~b}$ & $101,06 \mathrm{ab}$ & $88,85 \mathrm{~b}$ & $111,80 \mathrm{a}$ & 6,98 \\
$\mathrm{~g} / \mathrm{kg} L W^{0.75}$ & & & & & \\
\hline
\end{tabular}

Digestibilidade $(\%)$

Digestiblity (\%)

\begin{tabular}{llllll} 
MS (DM) & $65,74 \mathrm{a}$ & $69,33 \mathrm{a}$ & $66,35 \mathrm{a}$ & $66,58 \mathrm{a}$ & 4,44 \\
PB (CP) & $66,28 \mathrm{a}$ & $63,73 \mathrm{a}$ & $66,71 \mathrm{a}$ & $64,88 \mathrm{a}$ & 5,56 \\
EE & $64,25 \mathrm{a}$ & $64,63 \mathrm{a}$ & $64,70 \mathrm{a}$ & $54,07 \mathrm{~b}$ & 3,79 \\
CHOT (TCHO) & $67,04 \mathrm{a}$ & $72,16 \mathrm{a}$ & $67,50 \mathrm{a}$ & $68,42 \mathrm{a}$ & 4,43 \\
FDN (NDF) & $62,78 \mathrm{a}$ & $64,02 \mathrm{a}$ & $61,39 \mathrm{a}$ & $63,79 \mathrm{a}$ & 5,38 \\
FDA (ADF) & $63,07 \mathrm{a}$ & $67,91 \mathrm{a}$ & $63,12 \mathrm{a}$ & $55,97 \mathrm{a}$ & 9,88 \\
NDT (TDN) & $64,06 \mathrm{a}$ & $64,64 \mathrm{a}$ & $64,84 \mathrm{a}$ & $64,89 \mathrm{a}$ & 4,38 \\
NDT $^{1}(T D N)$ & $55,58 \mathrm{~b}$ & $59,09 \mathrm{a}$ & $55,79 \mathrm{~b}$ & $55,06 \mathrm{~b}$ & 1,48 \\
\hline
\end{tabular}

T - controle; PC - polpa cítrica. AEB - aditivo enzimático-bacteriano; E - emurchecimento.

Médias seguidas de letras distintas, na linha, são diferentes $(P<0,05)$.

1 Estimado (NRC, 2001).

C-Control: CiP-Citric pulp: EBA-Enzymatic-bacterial additive; $W$ - wilting

Means followed by distinct letters in the same row differ $(P<0.05)$.

${ }^{1}$ Estimated (NRC, 2001).

Henrique \& Bose (1992), em estudos com capim-elefante, e Stokes (1992), em silagem de gramíneas e leguminosas. Esses autores não detectaram efeito do aditivo enzimáticobacteriano sobre o consumo de MS. Entretanto, Meeske et al. (1992) e Fredeen \& McQueen (1993) trabalharam, respectivamente, com Digitaria eriantha e alfafa e obtiveram maior consumo de MS com o uso de aditivo. Neste trabalho, o consumo de MS da silagem produzida com AEB por novilhos sob suplementação com concentrado foi de 2,37\% PV, bem maior que o de 1,28 PV observado por Silva et al. (2004) para dieta constituída de $80 \%$ de silagem de capim-marandu produzida com inoculante (NUTRISILO) e $20 \%$ concentrado. De modo geral, pode-se inferir que o uso de aditivo enzimático-bacteriano na ensilagem não proporciona efeito consistente sobre o consumo de MS. Esta inferência é reforçada por Harrison et al. (1994), que, em revisão de literatura, demonstraram que os inoculantes bacterianos e suas associações com enzimas produzem efeitos variáveis sobre o consumo de MS.

Os dados referentes à digestibilidade dos nutrientes de dietas contendo silagens + concentrado são descritos na
Tabela 3. O emurchecimento diminuiu $(\mathrm{P}<0,01)$ a digestibilidade do EE, provavelmente em razão do (provável) menor consumo deste nutriente, atribuído à menor concentração na silagem, havendo maior influência do EE endógeno sobre o cálculo da digestibilidade. A digestibilidade dos demais nutrientes não foi afetada $(\mathrm{P}>0,05)$ pelo emurchecimento e está de acordo com as observações de Narciso Sobrinho et al. (1998), que, utilizando essa prática na ensilagem do capim-elefante, não observaram melhora na digestibilidade dos nutrientes em ovinos. Ribeiro et al. (2004), em estudo com silagem de capimmarandu, também não observaram efeito do emurchecimento sobre a digestibilidade in vitro da MS.

A PC não afetou $(\mathrm{P}<0,05)$ a digestibilidade dos nutrientes, entretanto, esperava-se melhora na digestibilidade da silagem produzida com este aditivo, em virtude de sua alta digestibilidade. Além disso, a PC proporcionou silagem de qualidade superior, confirmada pelo mais baixo $\mathrm{pH}$ e pelos menores teores de $\mathrm{N}_{-} \mathrm{NH}_{3}$ e FDA. Peres (1997), em estudo com ovinos, utilizaram $10 \%$ de $\mathrm{PC}$ na ensilagem de capimelefante e obteve aumento significativo (7\%) na digestibilidade da MS e nos valores dos nutrientes digestíveis totais (NDT), mas não detectou alterações na digestibilidade da PB, observando aumento apenas marginal na digestibilidade do EE e da FDA. Amaral et al. (2004) e Ribeiro et al. (2004) verificaram que o uso de PC na ensilagem de capim-marandu aumentou a digestibilidade in vitro da MS. Considerando observações de campo, Carvalho (1994) afirmou que a adição de $20 \%$ de PC na ensilagem de capim-elefante aumentou os teores de NDT de 56,2 para $60,8 \%(4,6 \%)$, próximo ao aumento observado neste trabalho, de 55,58 para $59,09 \%$ (3,5\%) com adição de $10 \%$ de PC.

O uso de aditivo enzimático-bacteriano não afetou $(\mathrm{P}<0,05)$ a digestibilidade dos nutrientes das silagens. De modo semelhante, Vilela et al. (1982), em experimento com com vacas, e Henrique \& Bose (1992), em estudo com ovinos, ambos utilizando silagem de capim-elefante, não detectaram efeito do uso de aditivo enzimático bacteriano sobre os valores do NDT e a digestibilidade dos nutrientes, respectivamente. Também não foi observado efeito deste tipo de aditivo sobre a digestibilidade in vitro da matéria orgânica da silagem de Digitaria eriantha (Meeske et al. 1992), da MS da silagem de gramínea + leguminosas (Stokes, 1992) e da MS da silagem de sorgo (Rodrigues et al., 2002), mas foi constatado aumento na digestibilidade in vivo da MO da silagem de Digitaria (Meeske et al., 1992) e da MS da silagem de alfafa (Fredeen \& McQueen, 1993). Para silagem de capim-marandu produzida com inoculante NUTROSILO, associada a $20 \%$ de concentrado, Silva et al . 
(2004) observaram, em novilhos, valores de digestibilidade da MS e FDN $10 \%$ menores e do EE $20 \%$ maiores em relação aos observados neste trabalho com o uso de aditivo enzimático-bacteriano (Tabela 3). Essas diferenças podem ser atribuídas ao corte mais tardio (105 dias) do capim e ao maior consumo de EE ocasionado pela presença de grão de soja na dieta (Silva et al., 2004). De modo geral, esses resultados confirmaram as observações de Harrison et al. (1994) de que os aditivos enzimático-bacterianos produzem efeitos variáveis sobre a digestibilidade da MS.

Considerando os valores de NDT das silagens puras (Tabela 3), estimados a partir de sua composição, conforme sugestão do NRC (2001), pode-se afirmar que a ausência de efeito dos tratamentos sobre a digestibilidade dos nutrientes das silagens está relacionada à qualidade não tão baixa das silagens e, principalmente, ao fornecimento de concentrado junto com as silagens.

A partir dos dados de consumo de MS, dos valores de NDT (Tabela 3) e das informações contidas no AFRC (1993), pode-se estimar, para animais com $200 \mathrm{~kg}$ de PV sob suplementação com $1 \mathrm{~kg}$ de concentrado, ganho de peso diário de $0,600 \mathrm{~kg} /$ animal, quando alimentados com a silagem controle ou aquela produzida com aditivo enzimáticobacteriano, e de $0,800 \mathrm{~kg} /$ animal para aqueles recebendo silagem produzida com polpa cítrica ou com forragem emurchecida. Estes ganhos de peso, embora estimados, distinguem o valor nutritivo das silagens obtidas com os diferentes tratamentos.

\section{Conclusões}

A adição de polpa cítrica e o emurchecimento da forragem podem ser recomendados como técnicas para ensilagem de Brachiaria brizantha (cv Marandu) colhida aos 60 dias de rebrota com $24 \% \mathrm{MS}$, pois melhoram a qualidade da silagem ao diminuírem os teores de nitrogênio amoniacal e estimularem o consumo de matéria seca. A adoção dessas técnicas depende, portanto, da relação custo:benefício, pois a silagem de capim-marandu colhido aos 60 dias de rebrota com $24 \%$ de MS, sem tratamento, apresentou valor nutritivo satisfatório. O uso de aditivo enzimáticobacteriano na ensilagem do capim-marandu é dispensável, pois não conserva o valor nutritivo da silagem.

\section{Literatura Citada}

AMARAL, R.C.; BERNARDES, T.F.; REIS, R.A. Influência da polpa cítrica peletizada nas alterações químicas das silagens de capim-marandu durante o processo fermentativo. In: REUNIÃO ANUAL DA SOCIEDADE BRASILEIRA DE ZooteCniA, 41., 2004, Campo Grande. Anais... Campo
Grande: Sociedade Brasileira de Zootecnia, [2004] CR-ROM. Forragicultura. FOR-417.

BERTO, J.L.; MÜHLBACH, P.R.F. Silagem de aveia preta no estádio vegetativo, submetida à ação de inoculantes e ao efeito do emurchecimento. Revista Brasileira de Zootecnia, v.26, n.4, p.651-658, 1997.

CARVALHO, M.P. Citros. In: SIMPÓSIO SOBRE NUTRIÇÃO DE BOVINOS, 6., 1994, Piracicaba. Anais... Piracicaba: Fundação de Estudos Agrários "Luiz de Queiroz", 1994. p.171-214.

COAN, R.M.; CONTATO, E.D.; REIS, R.A. et al. Qualidade Fermentativa e microbiológica das silagens de capim Brachiaria brizantha $\mathrm{cv}$. Marandu. In: REUNIÃO ANUAL DA SOCIEDADE BRASILEIRA DE ZOOTECNIA, 41., 2004. Campo Grande. Anais... Campo Grande: Sociedade Brasileira de Zootecnia, [2004] CR-ROM. Forragicultura. FOR-454.

CORRÊA, L.A.; POTT, E.B. Silagem de capim. In: SIMPÓSIO DE FORRAGICULTURA，2，2001, Lavras. Anais... Lavras: Universidade Federal de Lavras, 2001. p.255-271.

FREDEEN, A.H.; McQUEEN, R.E. Effect of enzyme additives on quality of alfafa/grass silage and dairy cow performance. Canadian Journal of Animal Science, v.73, p.581-591, 1993.

HAIGH, P.M. Effluent production from grass silages treated with additives and made in large-scale bunker silos. Grass and Forage Science, v.54, p.208-218, 1999.

HARRISON, J.H.; BLAUWIEKEL, R. Fermentation and utilization of grass silage. Journal of Dairy Science, v.77, p.32093235, 1994.

HENRIQUE, W.; BOSE, M.L.V. Efeito de aditivos enzimobacterianos sobre a qualidade da silagem de capim-elefante (Pennisetum purpureum, Schum.). Revista Brasileira de Zootecnia, v.21, n.3, p.429-438, 1992.

IGARASI, M.S. Controle de perdas na ensilagem de capim Tanzânia (Panicum maximum Jack. Cv Tanzânia) sob os efeitos do teor de matéria seca, do tamanho de partícula, da estação do ano e da presença de inoculante bacteriano. Piracicaba: Escola Superior de Agricultura "Luiz de Queiroz", 2002. 132p. Dissertação (Mestrado em Ciência Animal e Pastagem) - Escola Superior de Agricultura "Luiz de Queiroz", 2002.

JOHNSON, R.N.; BALINANI, T.L.; JOHNSON, L.L. et al. Corn plant maturity. II. Effect on "in vitro" cellulose digestibility and soluble carbohydrate content. Journal of Animal Science, v. 25, p.617-623, 1966

LAVEZZO, W. Ensilagem de capim elefante. In: SIMPÓSIO SOBRE MANEJO DA PASTAGeM, 10., 1993, Piracicaba. Anais... Piracicaba: Fundação de Estudos Agrários "Luiz de Queiroz", 1993. p.169-275.

MALAFAIA, P.A.M.; VIEIRA, R.A.M. Técnicas de determinação e avaliação dos compostos nitrogenados em alimentos para ruminantes. In: SIMPÓSIO INTERNACIONAL DE DIGESTIBILIDADE EM RUMINANTES, 1997, Lavras. Anais... Lavras: Fundação de Apoio ao Ensino, Pesquisa e Extensão, 1997. p.29-54.

McDONALD, P.; HENDERSON, N.; HERON, S. The biochemistry of silage. Marlow Bucks: Chalcombe Publications, 1991. 340p.

MEESKE, R.; BASSON, H.M.; CRUYWAGEN, C.W. The effect of a lactic acid bacterial inoculant with enzymes on the fermentation dynamics, intake and digestibility of Digitaria eriantha silage. Animal Feed Science and Technology, v.81, p.237-248, 1999.

MORAIS, J.P.G. Silagem de gramíneas tropicais. In: SIMPÓSIO SOBRE NUTRIÇÃO DE BOVINOS, 7., 1999, Piracicaba. Anais... Piracicaba: Fundação de Estudos Agrários "Luiz de Queiroz", 1999. p.89-95.

NARCISO SOBRINHO, J.; MATTOS, H.B.; ANDRADE, J.B. et al. Silagem de capim-elefante, em três estádios de maturidade, submetido ao emurchecimento. I - Produção e composição das forragens. Boletim da Indústria Animal, v.55, n.2, p.99111,1998 a. 
NARCISO SOBRINHO, J.; MATTOS, H.B.; ANDRADE, J.B. et al. Silagem de capim-elefante, em três estádios de maturidade, submetido ao emurchecimento. III - Valor nutritivo das silagens. Boletim da Indústria Animal, v.55, n.2, p.127-138, 1998b.

NUSSIO, L.G.; CASTRO, F.G.; SIMAS, J.M. et al. Effects of dry matter content and microbial additive on Tifton 85 (Cynodon dactylon spp.) wilted silage fermentation parameters. In: INTERNATIONAL GRASSLAND CONGRESS, 19., 2001, São Pedro. Proceedings... São Pedro: Fundação de Estudos Agrários "Luiz de Queiroz", 2001. p.790-792.

NUSSIO, L.G.; MANZANO, R.P.; AGUIAR, R.N.S. et al. Silagem do excedente de produção das pastagens para suplementação na seca. In: SIMPÓSIO SOBRE MANEJO E NUTRIÇÃO DE GADO DE CORTE, 2000, Goiânia. Anais... Goiânia: Colégio Brasileiro de Nutrição Animal, 2000. p.121-138.

PEREIRA, J.R.A.; REIS,R.A. Produção de silagem pré-secada com forrageiras temperadas e tropicais. In: SIMPÓSIO SOBRE PRODUÇÃO E UTILIZAÇÃO DE FORRAGENS CONSERVADAS, 2001, Maringá. Anais... Maringá: Universidade Estadual de Maringá, 2001. p.64-86.

PERES, J.R. Avaliação da polpa de citros seca e peletizada como aditivo na ensilagem de capim.elefante. Piracicaba: Escola Superior de Agricultura "Luiz Queiroz", 1997. 82p. Dissertação (Mestrado em Ciência Animal e Pastagem) - Escola Superior de Agricultura "Luiz de Queiroz", 1997.

PLAYNE, M.J.; McDONALD, P. The buffering constituents of herbage and of silage. Journal Science and Food Agriculture, v.17, n.2, p.264-268, 1966.

REIS, R.A.; ROSA,B. Suplementação volumosa: conservação do excedente das pastagens. In: SIMPÓSIO SOBRE MANEJO DA PASTAGEM, 18., 2001, Piracicaba. Anais... Piracicaba: Fundação de Estudos Agrários "Luiz de Queiroz", 2001. p.193-232.

REIS, R.A.; BERNARDES, T.F.; AMARAL, R. Teores de compostos nitrogenados do capim Marandu (Brachiaria brizantha, cv. Marandu) ensilado com polpa cítrica peletizada. In: REUNIÃO ANUAL DA SOCIEDADE BRASILEIRA DE ZOOTECNIA, 40., 2004, Campo Grande. Anais... Campo Grande: Sociedade Brasileira de Zootecnia, [2004] CR-ROM. Forragicultura. FORR-426.

RIBEIRO, J.L.; NUSSIO, L.G.; MARI, L. et al. Avaliação do valor nutritivo da silagem de capim Marandu submetido aos efeitos do teor de matéria seca, da estação do ano e da presença de inoculante bacteriano. In: REUNIÃO ANUAL DA SOCIEDADE BRASILEIRA DE ZOOTECNIA, 41., 2004, Campo Grande. Anais...Campo Grande: Sociedade Brasileira de Zootecnia, [2004] CR-ROM. Forragicultura. FOR-267.

RODRIGUES, P.H.M.; SENATORE, A.L.; ANDRADE, S.J.T. et al. Efeitos da adição de inoculantes microbianos sobre a composição bromatológica e perfil fermentativo da silagem de sorgo produzido em silos experimentais. Revista Brasileira de Zootecnia, v.31, n.6, p.2373-2379, 2002.

STATISTICAL ANALYSIS SYSTEM - SAS. SAS User's guide. Version 6, 4.ed., v.12. Cary: 1990.
ROTZ, C.A.; MUCK, R.E. Changes in forage quality during harvest and storage. In: FAHEY JR., G.C. (Ed.) Forage quality, evaluation, and utilization. Madison: American Society of Agronomy, 1994. p.828-868.

SILVA, B.C.; PEREIRA, O.G.; PEREIRA, D.H. et al. Consumo e digestibilidade aparente total e parcial dos nutrientes em bovinos de corte alimentados com dietas contendo silagem de Brachiaria brizantha cv. Marandu e concentrado em diferentes proporções. In: REUNIÃO ANUAL DA SOCIEDADE BRASILEIRA DE ZooteCniA, 41., 2004, Campo Grande. Anais... Campo Grande: Sociedade Brasileira de Zootecnia, [2004] CR-ROM. Forragicultura. FOR-081.

SILVA, D.J. Análise de alimentos: métodos químicos e biológicos Viçosa, MG: Universidade Federal de Viçosa, 1990. 166p.

SILVEIRA, A.C.; LAVEZZO, W.; SILVEIRA FILHO, S. et al. Consumo de silagens de capim-elefante (Pennisetum purpureum, Schum) submetidas a diferentes tratamentos. Revista Brasileira de Zootecnia, v.9, n.2, p.306-320, 1980.

STOKES, M. R. Effects of an enzyme mixture, an inoculante, and their interaction on silage fermentation and dairy production. Journal of Dairy Science, v.75, p.764-773, 1992.

VILELA, D. Aditivos para silagem de plantas de clima tropical. In REUNIÃO ANUAL DA SOCIEDADE BRASILEIRA DE ZOOTECNIA, 35., SIMPÓSIO SOBRE ADITIVOS NA PRODUÇÃO DE RUMINANTES E NÃO-RUMINANTES, 1998, Botucatu. Anais... Botucatu: Sociedade Brasileira de Zootecnia, 1998. p.73-108.

VILELA, D.; CRUZ, G. M.; CARVALHO, J.L.H. Efeito de alguns aditivos sobre a qualidade valor nutritivo da silagem de capim-elefante. Coronel Pacheco: Embrapa Gado de Leite, 1982. 15p (Circular Técnica, 15).

WILKINSON, J. M. Additives for ensiled temperate forage crops. In: REUNIÃO ANUAL DA SOCIEDADE BRASILEIRA DE ZOOTECNIA, 35., SIMPÓSIO SOBRE ADITIVOS NA PRODUÇÃO DE RUMINANTES E NÃO-RUMINANTES, 1998, Botucatu. Anais... Botucatu: Sociedade Brasileira de Zootecnia, 1998. p.53-72.

WRIGHT, D.A.; GORODON, F.J.; STEEN, R.W.J. et al. Factors influencing the response in intake of silage and animal performance after ensiling: a review. Grass and Forrage Science, v.55, p.1-13, 2000. 